\title{
Chronic Administration of Serotonergic Antidepressants Attenuates the Subjective Effects of LSD in Humans
}

\author{
Katherine R. Bonson, Ph.D., Joshua W. Buckholtz, and Dennis L. Murphy, M.D.
}

This study investigates the possible interactions of antidepressant agents and hallucinogens in humans through structured interviews using a standardized questionnaire. Volunteer subjects recruited through announcements placed on the Internet or other sources were asked to describe the somatic, hallucinatory, and psychological effects of self-administered LSD prior to and during chronic administration of an antidepressant. Truenty-eight out of 32 subjects $(88 \%)$ who had taken an antidepressant with inhibitory effects on serotonin (5-HT) reuptake (fluoxetine, paroxetine, sertraline, trazodone) for

KEY WORDS: LSD; Hallucinogen; Antidepressant; Serotonin reuptake inhibitor; Human studies

Antidepressant drugs are among the most frequently prescribed therapeutic agents in the world. Although recent reviews have focused on the interactions of antidepressants with other medically prescribed drugs (Birkhimer et al. 1984; Spina and Perucca 1994), less attention has been paid to the interactions of antidepressants with drugs that are used in a social or recreational manner. The 1993 National Household Survey on Drug Abuse (U.S. Department of Health and Human Services 1993) estimated that $8.7 \%$ of Americans have used hallucinogens at some point in their lifetime. Although this

From the Laboratory of Clinical Science, National Institute of Mental Health, Bethesda, MD.

Address correspondence to Dr. Katherine R. Bonson, Laboratory of Clinical Science, National Institute of Mental Health, Building 10, Room 3D41, Bethesda, MD 20892. E-mail: kbonson@codon.nih.gov

Received February 27, 1995; revised July 3, 1995; accepted July 19 , 1995. over 3 weeks had a subjective decrease or virtual elimination of their responses to LSD. An additional subject who had taken fluoxetine for only 1 week had an increased response to LSD. These data are in contrast to our previous study that reported increased responses to LSD during chronic administration of tricyclic antidepressants or lithium. Possible mechanisms of action for the effects from serotonergic antidepressants involve $5-\mathrm{HT}_{2}$ and $5-\mathrm{HT}_{1 \mathrm{~A}}$ receptors, changes in extracellular brain serotonin concentrations, and changes in brain catecholamine systems.

[Neuropsychopharmacology 14:425-436, 1996]

figure is relatively low compared to that for the other drugs that are used in a nonmedical setting, it does translate to 18 million individuals in the United States who have used LSD or similar agents.

Early clinical investigations demonstrated that chronic administration of the monoamine oxidase inhibitors (MAOIs) isocarboxazid (Resnick et al. 1964) or nialamide (Dytrych 1965; Grof and Dytrych 1965) markedly attenuated the subjective experiences of humans to LSD. We have recently reported that two individuals who were chronically taking MAOIs also described diminished responses to LSD; this was in contrast to eight other individuals taking lithium or the tricyclic antidepressants imipramine, desipramine, or clomipramine who had exaggerated responses to LSD (Bonson and Murphy in press). A single previous case report in the literature indicated that chronic administration of the serotonin reuptake inhibiting antidepressant fluoxetine reduced the hallucinogenic effects of LSD (Strassman 1992). There is also evidence that the chronic administration of fluoxetine added to ongoing neuroleptic treat- 
ment in schizophrenic patients can reduce hallucinations by 30\% (Goff et al. 1990). In this article we present systematically collected information from 33 individuals who had experience with LSD during the time that they were taking serotonin reuptake inhibitors (SRIs).

\section{METHODS}

Subjects for this retrospective study were identified through announcements placed on selected computer Internet news groups ("alt. drugs," "alt. psychedelics," "sci.med.psychobiology," "rec.music.gdead") and in a local alternative newspaper requesting an interview with hallucinogen users who had ingested LSD or other hallucinogens during the time that they had been taking a physician-prescribed antidepressant. Similar announcements were also placed in a newsletter with broad circulation to people interested in psychedelic drugs. Additional subjects volunteered after hearing about the study by word of mouth or were referred to us by other scientists and clinicians.

A structured interview was conducted orally or in written form and consisted of several parts: (1) Information about the antidepressant treatment (drug, daily dose, length of time on antidepressant when hallucinogen consumption occurred, reason for being placed on the antidepressant); (2) information about other drugs that the subject used on a regular basis, including prescription and recreational or social drugs; (3) information concerning the phenomenological effects of a hallucinogen that had been taken during antidepressant treatment. This question was asked in terms of whether the experience during antidepressant treatment was subjectively unchanged, increased, or decreased in comparison to times the person had taken a similar dose of the same hallucinogen prior to or after antidepressant use, or in comparison to the experience of a friend who was not taking antidepressants but had taken a similar dose of the same hallucinogen at the same time. The various points that were asked about followed the general time course of the effects of a hallucinogen, including the time it took for the subject to get high, alterations in somatic, hallucinatory, or psychological effects, the total time the subject was high, aftereffects or alterations in sleep, and an assessment of the overall experience; (4) information, if available, about whether the response a subject had to LSD was changed during the weeks following discontinuation of the antidepressant.

In order for a report from a subject to be considered usable, the subject must have had a "control" condition with which to compare the current hallucinogenic experience. This consisted of either a personal prior experience with a similar dose of LSD while the subject was not taking an antidepressant $(n=29)$ or the experience of a friend who was not taking an antidepressant but who had taken the same dose of the same hallucinogen at the same time as the subject $(n=30)$. All subjects who wished to participate in this study were assured of confidentiality prior to being interviewed. A complete copy of the structured interview is available from the authors upon request.

\section{REPRESENTATIVE CASE REPORTS}

\section{Fluoxetine}

$\mathrm{O}$, a 34-year-old male, had extensive experience with hallucinogens. In response to chronic depression, he had been placed on $20 \mathrm{mg} /$ day of fluoxetine. After 6 weeks of taking the antidepressant, his depression symptoms had considerably improved, and he ingested approximately $250 \mu \mathrm{g}$ of LSD. Upon "quite a bit of psychological effort" he experienced very slight somatic stimulation and "minor" hallucinations limited to bright visual patterns on blank walls. These mild effects were greatly delayed in their onset. There was little in terms of psychological response. Overall, the subject likened the effects as similar to those caused by $75 \mu \mathrm{g}$ of LSD. The total amount of time he felt the effects of the LSD was approximately 5 hours, which he stated was a significant reduction from a more normal 10 hours. There was no alteration in sleep. In contrast, a friend of the subject took a "moderate" dose $(100 \mu \mathrm{g})$ of LSD from the same batch and had a "normal" experience for the amount of hallucinogen taken. The subject had sampled a $250 \mu \mathrm{g}$ dose of LSD from the same batch prior to antidepressant treatment and noted that he had experienced an "overwhelming" response.

\section{Sertraline}

AA, a 36-year-old male, had extensive experience with hallucinogens. He had taken $100 \mathrm{mg} /$ day of sertraline for 3 weeks for depression when he ingested approximately $200 \mu \mathrm{g}$ of LSD. He reported that he did not feel any effects from the LSD whatsoever. This left him "dumbfounded," especially since he had taken a similar dose of LSD from the same batch before he had started taking sertraline and had "a rather intense experience." A friend of the subject took approximately $200 \mu \mathrm{g}$ of LSD from the same batch during a similar period and experience a full hallucinatory effect.

Following several months off sertraline, the subject's psychiatrist put him back on the antidepressant. After 3 weeks of sertraline use in this new phase, the subject once again took LSD from the same batch as before. This time, taking approximately $300 \mu \mathrm{g}$ of LSD, he was able to discern some limited effects from the hallucinogen. However, he reported that the experience qualitatively was equivalent to taking only $100 \mu \mathrm{g}$ of LSD under conditions when he was not taking an antidepressant. A friend of the 
subject took $100 \mu \mathrm{g}$ of LSD from the same batch and described effects that were similar in intensity to those experienced by the subject.

\section{Paroxetine}

$\mathrm{EE}$, a 35-year-old male, had extensive experience with hallucinogens. He ingested approximately $150 \mu \mathrm{g}$ of LSD following a 3-week course of paroxetine ( $20 \mathrm{mg} /$ day) for depression. After an hour, the subject felt only minor "proprioceptive distortions" and "mild" hallucinations that lasted for about 30 minutes. There were no further sensations over the next few hours that he could associate with the ingestion of LSD. The subject experienced no changes in sleep. A friend of the subject took approximately $150 \mu \mathrm{g}$ of LSD from the same batch and had a "normal" hallucinatory experience.

The subject ingested the same dose of LSD again after 5 weeks of paroxetine use and experienced no effects of the hallucinogen at all. On both occasions he took the LSD from a batch he used prior to beginning paroxetine. Before antidepressant use, $150 \mu \mathrm{g}$ LSD from this batch had induced typical somatic, hallucinatory, and psychological effects.

\section{SUMMARY OF CASE REPORTS}

A total of 33 individuals (eight women, twenty-four men, one anonymous), ranging in age from 15 to 37 , participated in this study by completing a structured interview. Although case reports for each of these subjects were submitted with the manuscript, their length precluded publication. They are available upon request from the authors and are summarized in Table 1 . All but four of these subjects were placed on an antidepressant for treatment of depression; two subjects had been prescribed fluoxetine for either anxiety or posttraumatic stress disorder (PTSD), one individual had been prescribed sertraline for attention deficit disorder (ADD), and one individual had been taking paroxetine for "stress." Although this was not a requirement for inclusion, all subjects who were interviewed had taken an antidepressant for at least 3 weeks before ingesting a hallucinogen, with the exception of one subject who reported on an experience with LSD after only 1 week of fluoxetine use. Twenty-six of the 33 subjects in this study had either extensive or moderate previous experience with a range of LSD doses prior to antidepressant use and were therefore able to give meaningful discriminative assessments of alterations in their responses to hallucinogens while they were taking an antidepressant. Thirty subjects had friends who were not taking an antidepressant who had taken the same dose of LSD from the same batch as the subject, thus providing reference experiences with which the subjects could compare their experiences. In addi- tion, 15 subjects had taken LSD from the same batch both before and during antidepressant treatment.

The results from this investigation indicate that subjective responses to LSD appear to be generally reduced by the chronic administration of antidepressants with primary serotonin reuptake effects. The typical effects of LSD follow a course that includes the early appearance of sympathomimetic stimulation (somatic effects), which continues throughout the 8- to 10-hour duration of the experience; the appearance of colors, patterns, and distortions in the visual field (hallucinatory effects), which peaks in about 4 hours; and introspective or philosophically oriented thoughts (psychological effects), which last through the end of the experience (Freedman 1969). In the present study, 28 of 32 subjects $(88 \%)$ reported that when they self-administered LSD during a medically prescribed regimen of an SRI (fluoxetine, sertraline, or paroxetine) of 3 or more weeks, there was a moderate to marked decrease in their usual responses to LSD. The data we present are consistent with a previous case report of a decrease in the effects of LSD in a person who had been chronically taking fluoxetine (Strassman 1992).

In conducting a retrospective study, certain issues of potential bias arise. Because the individuals who responded to our call for subjects were self-selected, it is possible that only those who had a decreased experience with hallucinogens while taking antidepressants were interviewed. However, because our announcements stated only that we wished to speak with those who had combined these two classes of drugs, there was no indication of our hypothesis that chronic antidepressant use could change the hallucinogenic experience in a particular direction. In fact, many subjects commented that they responded to our request for study participants because they simply wanted to contribute to scientific knowledge about hallucinogens.

In addition, we collected data not only from those who were taking serotonergic antidepressants but also from individuals who were being treated with other classes of antidepressants. These results, published elsewhere, indicated a differential response pattern to LSD taken in conjunction with the non-SRI antidepressant treatments (Bonson and Murphy in press). Briefly, individuals who were chronically taking tricyclic antidepressants or lithium (alone or in combination with tricyclic antidepressants) had a potentiation of their response to LSD. In contrast, individuals who had been chronically taking MAOIs had a reduced response to LSD similar to that reported in the present study. These data suggest that the chronic administration of different classes of antidepressants may differentially affect serotonin and other neurotransmitter systems in the brain that are activated by LSD.

To avoid possible investigator influence, a standardized questionnaire was used. Although our survey relies on memory, all subjects interviewed felt quite confident that their accounts were accurate, usually because 
Table 1. Effects of Serotonin Reuptake Inhibitors on Human Responses to LSD

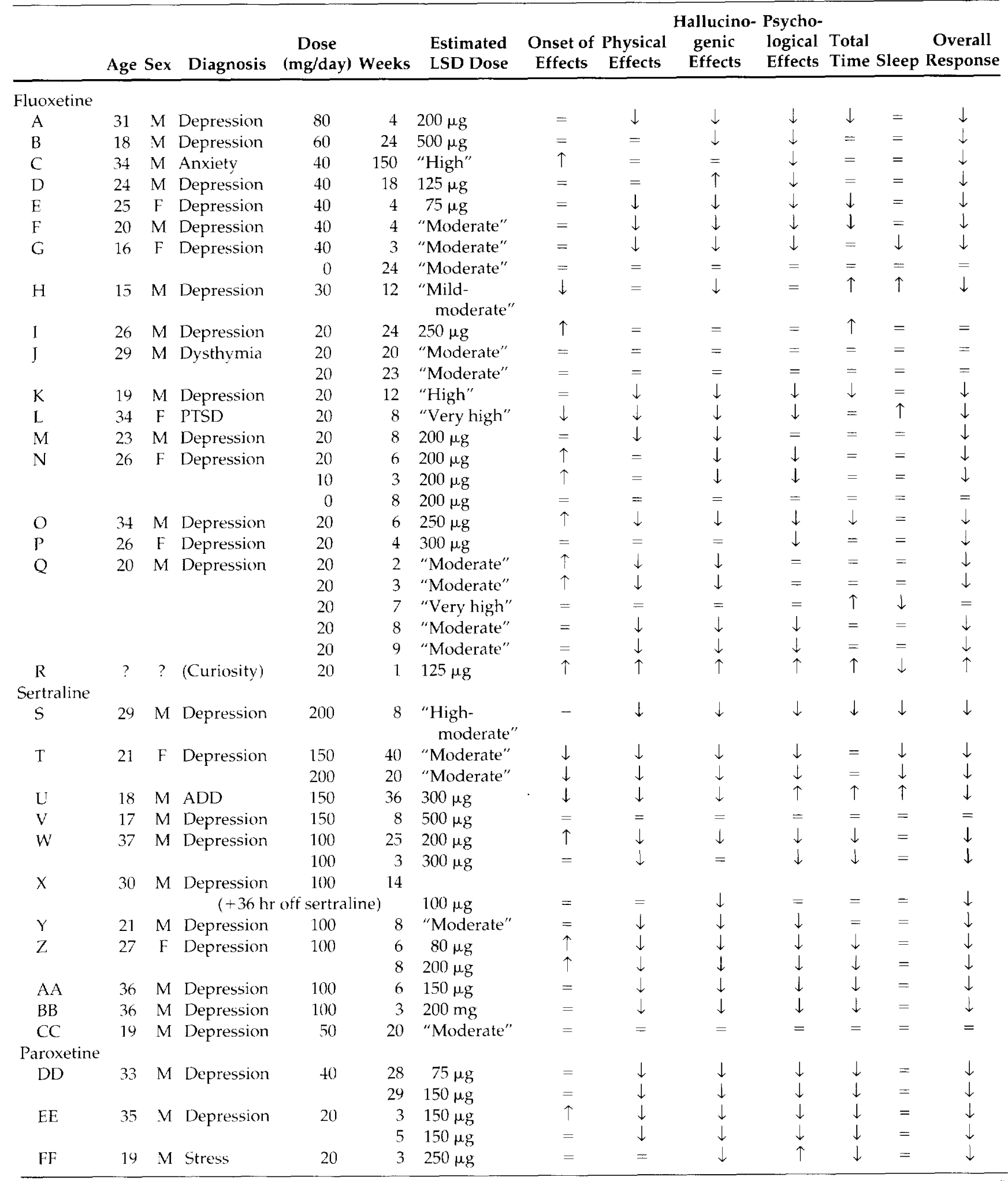


Table 1. (continued)

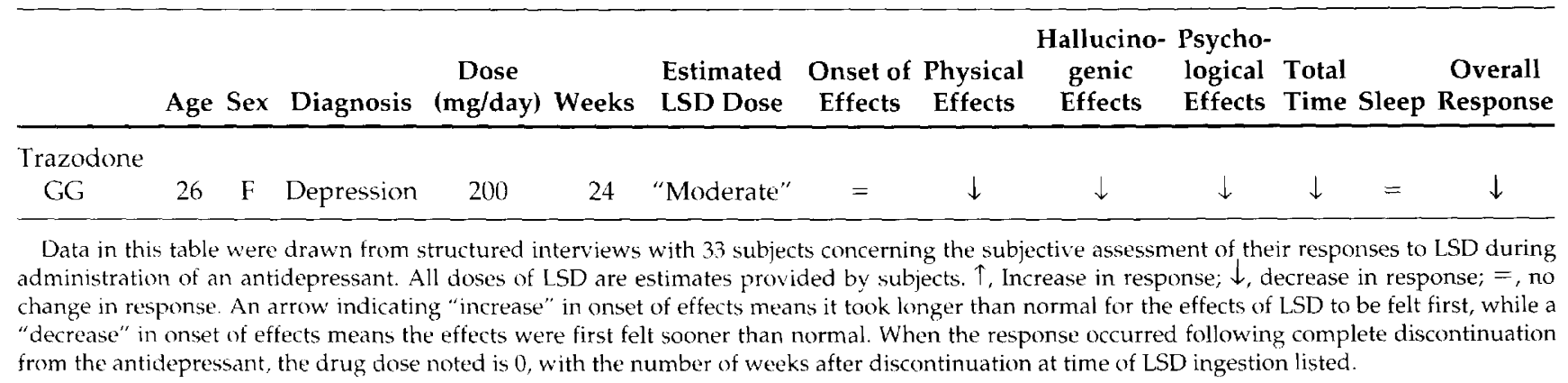

they were so surprised not to have had a usual response to the hallucinogen while taking an SRI. In answering the "overall response" summation question, subjects based their answer on those aspects of the LSD experience that were most important to them subjectively.

Finally, there is the issue of whether our subjects had a reduced response to hallucinogens not only because of chronic SRI use but also because they had underlying psychobiological alterations resulting from depression. All 28 subjects who had been depressed stated that they were either in partial or complete remission from their depression following chronic antidepressant treatment. The other four subjects with other diagnoses also had a similar lack of response to LSD.

The majority of subjects interviewed had been taking the antidepressant fluoxetine for 3 or more weeks when they ingested LSD $(n=17)$. Fifteen $(88 \%)$ reported moderate to marked reductions in their somatic, hallucinatory, and/or psychological responses to LSD when they had ingested "moderate" to "high" doses of the hallucinogen after taking fluoxetine for over 3 weeks. One subject noted that although he had no real response to LSD at "moderate" doses while taking fluoxetine, he was able to experience a full hallucinogenic response when he ingested a "very high" LSD dose, estimated to be approximately $400 \mu \mathrm{g}$. The responses to LSD did not appear to be dependent on the dose of fluoxetine being taken, because subjects reported decreased responses to LSD when they were taking doses of $80 \mathrm{mg} /$ day $(n=1), 60$ $\mathrm{mg} /$ day $(n=1), 40 \mathrm{mg} /$ day $(n=5)$, or $20 \mathrm{mg} /$ day $(n=$ 7 of 9). Two subjects who had been chronically taking $20 \mathrm{mg} /$ day of fluoxetine experienced no change in their response to LSD.

In subjects taking sertraline, 100 to $200 \mathrm{mg} /$ day of this antidepressant was associated with a decrease in most major effects of moderate doses of LSD in eight of nine individuals. One subject taking $100 \mathrm{mg} /$ day of sertraline reported that although there was a decrease in his response to a "moderate" dose of LSD, when he took a much higher $(300 \mathrm{mg})$ dose of LSD, he was finally able to experience some effect from the hallucinogen. One subject taking $50 \mathrm{mg} /$ day of sertraline did not experience any change in response to the hallucinogen. Three subjects chronically taking paroxetine reported a reduction in the effects from LSD. Similarly, a single subject who reported on an experience with LSD after chronic administration of trazodone also had a decrease in her response to the effects of the hallucinogen.

It is unlikely that the reduced response of most subjects to LSD while they were taking serotonergic antidepressants is the result of tolerance because none of the subjects ingested LSD more frequently than once a week; tolerance to LSD dissipates after 3 to 4 days (Strassman 1984). In addition, none of the other drugs that subjects were consuming on a regular or intermittent basis (such as asthma medication or birth control pills) appeared to interfere with the ability of serotonergic antidepressants to decrease the effects of LSD.

Several subjects were able to give information about their responses to LSD during dosage reduction or following interruption or cessation of SRI treatment. One subject who purposefully discontinued his sertraline daily dose 36 hours in advance of ingesting LSD still experienced the typical decrease in response to the hallucinogen that was reported by subjects who had taken their antidepressant the day of hallucinogen use. Another subject who took LSD after being on a reduced dose of fluoxetine for several weeks also had a continuing reduced response to the LSD. This could have been expected considering that fluoxetine has a half-life of 1 to 3 days and that its active metabolite norfluoxetine has a half-life of 7 to 15 days after single-dose administration (Lucas 1992) and chronic administration is accompanied by measurable drug levels for as long as 28 days (Pato et al. 1991). Finally, two subjects reported that a month after fluoxetine discontinuation their responses to LSD had fully returned to normal. These data support the theory that it is the alterations in neurotransmitter systems resulting from chronic administration of serotonergic antidepressants that are the critical factors in the reduced responses to LSD.

One subject in the present study ingested a hallucinogen after only 1 week of fluoxetine treatment and noted a considerable increase in response to LSD. It is possible that this effect may be related to statements made by many of our subjects that they themselves had unusual 
responses to an SRI alone during the initial period of pharmacotherapy. The most common description of this phenomenon was that subjects felt as though they were experiencing the somatic sensations (and occasionally full hallucinatory effects) that normally occur in the initial hours following hallucinogen ingestion. These reports may be consistent with anecdotal evidence from patients reporting "strange" sensations during the start of serotonergic antidepressant medication that resemble anxiety or sympathomimetic stimulation. However, it should be noted that the subjects in the present study were able to distinguish these early-onset sensations from SRIs as being dissimilar from the effects of other sympathomimetics such as amphetamine or cocaine, based on their previous experience with these stimulants. Although such sensations are not universal for all individuals who take SRIs, they have been reinforcing enough in some persons that five case reports exist concerning individuals with histories of drug abuse who have actively sought fluoxetine strictly for purposes of misusing the antidepressant (Wilcox 1987; Goldman et al. 1990; Pagliaro and Pagliaro 1993; Gross 1994; Tinsley et al. 1994).

It has been suggested that early-onset stimulation from SRIs may especially occur in patients who have a previous history of hallucinogen use and that this population is at risk for "flashbacks" during the first weeks of treatment with this class of antidepressants (Markel et al. 1994). However, an alternative explanation is that if such phenomena occur in individuals who have used hallucinogens, such individuals may simply be in a better position to identify accurately the sensations as resembling the early phase of LSD response than others who have not had exposure to hallucinogens. It has been shown that acute administration of fluoxetine can increase the inhibitory effects of LSD at serotonin raphe neurons, suggesting a potentiation effect (Trulson and Crisp 1986). Therefore, it is possible that the subject in the present study who reported an increase in response to LSD after only 1 week of fluoxetine use was experiencing a potentiation based on the interaction of two drugs that can produce similar initial effects.

\section{DISCUSSION}

\section{Action of LSD in the Brain: 5- $\mathrm{HT}_{2}$ Receptors}

The neuropharmacology of LSD in humans and other animals is complex and incompletely understood. It has long been known that LSD has high affinities for different neurotransmitter binding sites in brain, including those for serotonin, dopamine, and norepinephrine receptors (Closse et al. 1984). In terms of the human hallucinogenic response, it has been suggested that the unique behavioral effects of LSD may rely on stimulation of 5- $\mathrm{HT}_{2}$ receptor subtypes (Glennon 1990; Glennon et al. 1992). This theory is based on the strong correlations between the ability of drugs such as LSD to bind with high affinity to $5-\mathrm{HT}_{2}$ receptors (Pierce and Peroutka 1988; Titeler et al. 1988; Pierce and Peroutka 1989; Pierce et al. 1992) and their potency to induce hallucinogenic responses in humans (Glennon et al. 1984; Titeler et al. 1988; Pierce and Peroutka 1989; Sadzot et al. 1989). LSD has been shown to act as a partial agonist in stimulating phosphoinositol hydrolysis in the frontal cortex and choroid plexus, indicating activation of the second messenger systems associated with $5-\mathrm{HT}_{2 \mathrm{~A}}$ and $5-\mathrm{HT}_{2 \mathrm{C}}$ receptors, respectively (Sanders-Bush and Breeding 1988; Sanders-Bush et al. 1988; Burris et al. 1991).

Chronic administration of LSD has been shown to downregulate preferentially $5-\mathrm{HT}_{2}$ receptors without altering postsynaptic $5-\mathrm{HT}_{1 \mathrm{~A}}$ sites (Buckholtz et al. 1985, 1988), and this change has been demonstrated to parallel the development and loss of behavioral tolerance (Buckholtz et al. 1990). In drug discrimination studies the interoceptive cue to LSD has been shown to be blocked by acute administration of 5- $\mathrm{HT}_{2}$ antagonists, but not by antagonists with affinity at $5-\mathrm{HT}_{1 \mathrm{~A}}$ sites (White et al. 1983; Colpaert et al. 1985; Nielsen 1985; Nielsen et al. 1985; Cunningham and Appel 1987; Winter and Rabin 1988; Arnt 1989; Callahan and Appel 1990).

\section{Action of LSD in the Brain: $5-\mathrm{HT}_{1 \mathrm{~A}}$ Receptors}

Although 5- $\mathrm{HT}_{2}$ receptors appear to play a critical role in the hallucinogenic response to LSD, stimulation of presynaptic $5-\mathrm{HT}_{1 \mathrm{~A}}$ receptors also contributes to the effects of this drug (Glennon et al. 1984). LSD has long been known to produce a total inhibition of firing in the raphe nucleus (Aghajanian and Haigler 1975), where (based on electrophysiological and calcium influx measures) LSD acts as a full 5- $\mathrm{HT}_{1 \mathrm{~A}}$ agonist (Penington and Fox 1994), thereby decreasing the efflux of $\left[{ }^{3} \mathrm{H}\right] 5-\mathrm{HT}$ in raphe neurons (Gallager and Aghajanian 1975), a fact indicative of autoreceptor agonist effects. A primary or exclusive role for presynaptic $5-\mathrm{HT}_{1 \mathrm{~A}}$ sites in hallucinogenic response to LSD has been discounted, however, on the basis of several types of evidence: The duration of behavioral effects outlasts alterations in raphe firing rate changes; raphe neurons still remain responsive to the effects of LSD during periods of behavioral tolerance; phenethylamine hallucinogens such as DOM or mescaline produce no change in raphe activity; and very low doses of LSD may produce large changes in behavior but induce only relatively small changes in raphe activity (Trulson et al. 1981).

While stimulation of presynaptic $5-\mathrm{HT}_{1 \mathrm{~A}}$ sites may be insufficient by itself to induce hallucinogenesis, activation of these receptors may work in conjunction with $5-\mathrm{HT}_{2}$ receptors to produce the classic effects of LSD. Support for this theory is provided in studies where the effects of LSD in the Behavior Pattern Monitor could be fully abolished by a combination of the $5-\mathrm{HT}_{2 \mathrm{~A}} / 5-\mathrm{HT}_{2 \mathrm{C}}$ receptor antagonist ritanserin and the $5-\mathrm{HT}_{1 \mathrm{~A}}$ antagonist propra- 
nolol, but not by administration of either of these agents alone (Mittman and Geyer 1989, 1991).

\section{Interaction of LSD and SRIs: 5-HT 2 Sites}

If $\mathrm{LSD}$ is acting at the $5-\mathrm{HT}_{2}$ and $5-\mathrm{HT}_{1 \mathrm{~A}}$ receptors, a downregulation of these sites could reduce the behavioral response to LSD. It has long been recognized that chronic administration of many classes of antidepressants decrease the number of $5-\mathrm{HT}_{2}$ receptors in various brain regions (Heninger and Charney 1987; Murphy et al. 1987). Thus, a downregulation of $5-\mathrm{HT}_{2}$ receptors might account for the decrease in hallucinogenic responses reported in the present study by individuals who had been taking a serotonin-selective antidepressant for several weeks or more. The evidence for this theory is mixed, however, as SRIs less uniformly affect 5- $\mathrm{HT}_{2}$ receptors than do tricyclic antidepressants. Although two studies have shown that chronic administration of fluoxetine induces a decrease in $5-\mathrm{HT}_{2}$ binding sites in some rat brain regions (Stolz et al. 1983; Wamsley et al. 1987), others have observed that chronic fluoxetine can increase 5- $\mathrm{HT}_{2}$ sites (Dumbrille-Ross and Tang 1983; Klimek et al. 1994) or not affect 5- $\mathrm{HT}_{2}$ sites (Peroutka and Snyder 1980; Snyder and Peroutka 1982; Fuxe et al. 1983; Baron et al. 1988; Willner 1989; Goodnough and Baker 1994). However, chronic administration of zimelidine, another serotonin-selective antidepressant, has been shown to induce a decrease in tritiated LSD binding sites in rodent cerebral cortex (Fuxe et al. 1981).

Despite a lack of consistency in receptor binding studies, behavioral data support a theory that chronic administration of serotonergic antidepressants can alter functional responses at $5-\mathrm{HT}_{2}$ receptors. Thus, long-term administration of SRIs has been shown to reduce the head-twitch response in rodents elicited by 5 -HTP or 5-MeO-DMT, a behavior associated with stimulation of 5- $\mathrm{HT}_{2}$ receptors (Fuxe et al. 1981; Goodwin et al. 1984; Willner 1989; Maj and Moryl 1992, 1993). Chronic administration of SRIs also have been shown to decrease the hypoactivity elicited by m-chlorophenylpiperazine, indicating a probable reduction in $5-\mathrm{HT}_{2} \mathrm{C}$ receptor responsiveness (Maj and Moryl 1992, 1993; Kennett et al. 1994).

\section{Interactions of LSD and SSRIs: $5-\mathrm{HT}_{1 \mathrm{~A}}$ Sites}

Studies investigating long-term administration of serotonin-selective antidepressants indicate a pattern of reduced electrophysiological responses at $5-\mathrm{HT}_{1 \mathrm{~A}}$ receptors. Chronic citalopram administration blocked the decrease in firing rate in dorsal raphe neurons normally seen following direct or intravenous LSD (de Montigny et al. 1990). A similar effect on the responsivity to LSD was seen in dorsal raphe neurons after chronic administration of zimelidine, indicating desensitization of 5-HT autoreceptors (Blier and de Montigny 1983). Chronic cit- alopram administration decreased the inhibitory effect of LSD on tritiated 5-HT release from the raphe area, indicating a downregulation of the $5-\mathrm{HT}_{1 \mathrm{~A}}$ autoreceptor (Moret and Briley 1990a, 1990b). However, chronic administration of fluoxetine did not alter the inhibitory response of forebrain neurons to either LSD or 5-HT (de Montigny and Aghajanian 1978).

In binding studies, chronic administration of fluoxetine has been shown to cause a decrease in $5-\mathrm{HT}_{1}$ receptor density in 15 studies, whereas six other studies did not find a change in 5-HT 1 binding (Beasley et al. 1992; Newman et al. 1993; Klimek et al. 1994). However, it has been noted previously that the $5-\mathrm{HT}_{1 \mathrm{~A}}$ site may not be easily regulated because chronic administration of $5-\mathrm{HT}_{1 \mathrm{~A}}$ agonists fail to cause either up- or downregulation of 5- $\mathrm{HT}_{1 \mathrm{~A}}$ receptors (Schechter et al. 1990; Murthy and Pranzatelli 1992), so binding site assays may not be a definitive indicator of $5-\mathrm{HT}_{1 \mathrm{~A}}$ receptor function. Evidence exists, however, that adaptation can occur in the second messenger system associated with the $5-\mathrm{HT}_{1 \mathrm{~A}}$ site: chronic administration of SRIs induced a decrease in the blockade of forskolin-stimulated adenylate cyclase by $5-\mathrm{HT}$, suggesting a reduction in $5-\mathrm{HT}_{1 \mathrm{~A}}$ responses (Newman et al. 1993).

A few behavioral studies exist that show that chronic administration of sertraline or citalopram decreased some behaviors associated with the stimulation of presynaptic 5- $\mathrm{HT}_{1 \mathrm{~A}}$ sites (Maj and Moryl 1992), even though chronic administration of these antidepressants did not change $\left[{ }^{3} \mathrm{H}\right]-8-\mathrm{OH}-\mathrm{DPAT}$ binding nor forskolin-stimulated adenylate cyclase responses (Hensler et al. 1991). In addition, chronic administration of SRIs decreased the hormonal response to 8-OH-DPAT ( $\mathrm{Li}$ et al. 1993a, 1993b). However, chronic fluoxetine has not been shown to alter $5-\mathrm{HT}_{1 \mathrm{~A}}$-mediated behaviors such as the serotonin syndrome induced by acute administration of 8-OH-DPAT (Maj and Moryl 1993).

\section{LSD as an Antagonist Following Chronic SRIs}

Although most studies indicate that the classic effects of LSD are induced by its agonist actions at the $5-\mathrm{HT}_{2 \mathrm{~A}} /$ $5-\mathrm{HT}_{2 \mathrm{C}}$ and $5-\mathrm{HT}_{1 \mathrm{~A}}$ receptors, others have suggested that LSD is actually acting as an antagonist because the addition of GTP to binding assays does not have an effect on [ $\left.{ }^{3} \mathrm{H}\right]$ LSD binding at cortical 5- $\mathrm{HT}_{2}$ sites (Battaglia et al. 1983; Pierce and Peroutka 1988). However, studies using phosphoinositol turnover assays have suggested that LSD may be acting as a partial agonist without inverse agonist effects at $5-\mathrm{HT}_{2 \mathrm{~A}}$ receptors in the rat frontal cortex or in cloned $5-\mathrm{HT}_{2 \mathrm{~A}}$ receptors transfected into fibroblasts and at $5-\mathrm{HT}_{2} \mathrm{C}$ sites in the choroid plexus or in cloned $5-\mathrm{HT}_{2} \mathrm{C}$ receptors transfected into fibroblasts, with agonist/antagonist effects dependent on available 5-HT concentrations (Sanders-Bush and Breeding 1988; Sanders-Bush et al. 1988; Burris and Sanders-Bush 1992; 
Westphal and Sanders-Bush 1994). This conclusion is supported by the demonstration that nanomolar concentrations of LSD can inhibit the stimulatory effects of micromolar concentrations of 5-HT on raphe firing (Pierce and Peroutka 1988). Recent studies indicate that chronic administration of SRIs can induce moderate increases in brain extracellular serotonin levels (Fuller 1994). One study showed that chronic administration of the SRI fluvoxamine increased serotonin levels in the frontal cortex but not in the raphe nuclei (Bel and Artigas 1993). These data were interpreted as suggesting that desensitization of $5-\mathrm{HT}_{1 \mathrm{~A}}$ receptors following acute increases in 5-HT during initial SRI administration might inactivate the negative feedback mechanism controlling $5-\mathrm{HT}$ release, thus allowing for the continuing increase in 5-HT levels after chronic antidepressant administration. The results from the present study, demonstrating that chronically administered serotonergic antidepressants can decrease the response humans have to LSD, would be consistent with a hypothesis that an increase in serotonin brought about by long-term exposure to serotonergic antidepressants allows LSD to act as an antagonist and thus not produce its classic hallucinogenic effects.

\section{Contributions from Other 5-HT Receptors and Catecholamine Systems}

LSD has binding affinity at the $5-\mathrm{HT}_{1 \mathrm{D}}$ human terminal autoreceptor that approximates its affinity for the $5-\mathrm{HT}_{2 \mathrm{~A}}$, $5-\mathrm{HT}_{2} \mathrm{C}$, and 5- $\mathrm{HT}_{1 \mathrm{~A}}$ receptors (Table 2) (Hoyer 1989). There has been little investigation or consideration of the functional effects of $\mathrm{LSD}$ at $5-\mathrm{HT}_{1 \mathrm{D}}$ receptors, possibly because (1) the phenethylamine hallucinogens such as mescaline or DOM have low affinity for these receptors and (2) the rodent equivalent of the human $5-\mathrm{HT}_{1 \mathrm{D}}$ receptor, the terminal $5-\mathrm{HT}_{1 \mathrm{~B}}$ autoreceptor, has a 10 -fold lower affinity for LSD compared to any other serotonin receptor subtype (Hoyer 1989). More recently LSD has been shown to have low nanomolar affinity (Kd's of 1 to $5 \mathrm{nM}$ ) for the newly identified $5-\mathrm{HT}_{5 \mathrm{a}}, 5-\mathrm{HT}_{5 \mathrm{~b}}, 5-\mathrm{HT}_{6}$, and $5-\mathrm{HT}_{7}$ receptors, as well as slightly lower affinity for

Table 2. Affinity of LSD for 5-HT Receptor Subtypes

\begin{tabular}{lcl}
$\begin{array}{l}\text { 5-HT Receptor } \\
\text { Subtype }\end{array}$ & $\begin{array}{c}\text { Affinity } \\
\text { pKd (- } \log \text { mol/L) }\end{array}$ & \multicolumn{1}{c}{ Reference } \\
\hline $5-\mathrm{HT}_{1 \mathrm{~A}}$ & 8.6 & Hoyer 1989 \\
$5-\mathrm{HT}_{1 \mathrm{~B}}$ & 6.8 & Hoyer 1989 \\
$5-\mathrm{HT}_{1 \mathrm{D}}$ & 7.9 & Hoyer 1989 \\
$5-\mathrm{HT}_{1 \mathrm{E}}$ & 7.7 & Lovenberg et al. 1993a \\
$5-\mathrm{HT}_{2 \mathrm{~A}}$ & 8.6 & Hoyer 1989 \\
$5-\mathrm{HT}_{2 \mathrm{C}}$ & 7.9 & Hoyer 1989 \\
$5-\mathrm{HT}_{5 \mathrm{a}}$ & 8.8 & Erlander et al. 1993 \\
$5-\mathrm{HT}_{5 \mathrm{~b}}$ & 8.3 & Erlander et al. 1993 \\
$5-\mathrm{HT}_{6}$ & 8.9 & Monsma et al. 1993 \\
$5-\mathrm{HT}_{7}$ & 8.3 & Lovenberg et al. 1993b \\
\hline
\end{tabular}

the $5-\mathrm{HT}_{1 \mathrm{E}}$ receptor (Table 2). Little is currently known about the pharmacology and role in physiological functions of these recently identified receptor subtypes, although their molecular sequences, basic signal transduction mechanisms, and discrete localization in brain regions have been identified. Clearly, behavioral investigations are needed in this area to further our understanding of the importance of these additional serotonin receptors. Of some interest to our investigations of antidepressants and hallucinogens is the fact that the tricyclic antidepressants imipramine, clomipramine, amitriptyline, doxepine, and nortriptyline have $\mathrm{K}_{\mathrm{i}}$ 's in the range of 50 to $200 \mathrm{mM}$ for the $5-\mathrm{HT}_{6}$ receptor; the $\mathrm{K}_{\mathrm{i}}$ for fluoxetine, however, is considerably lower (1,770 nM) (Monsma 1993). Of perhaps greater pertinence, chronic fluoxetine administration to rodents has recently been reported to reduce significantly 5-HT 7 binding sites (Sleight et al. 1995); however, the role of this receptor in behavioral and physiological functions has not yet been elucidated.

Although serotonin systems appear to play a major role in the effects of LSD, the contributions of dopamine and norepinephrine neurotransmitter systems have also been investigated. LSD binds to postsynaptic dopamine receptors with moderate affinity (Creese et al. 1975; Burt et al. 1976) and has been shown to have dopamine agonist effects (Pieri et al. 1974). In regard to the effects of antidepressants on dopamine systems, one study reported that chronic administration of fluoxetine reduced dopamine concentrations in the nucleus accumbens and striatum (Gardier et al. 1994), and another study demonstrated only slight changes in dopamine levels (Caccia et al. 1992); this treatment did not alter amphetamineinduced locomotor behavior (Spyraki and Fibiger 1981; Martin-Iverson et al. 1983). LSD is known to produce sympathetic stimulation, and the LSD cue in drug discrimination studies is more completely blocked by agents that have combined catecholaminergic and serotonergic antagonist action than by antagonists with more selective action at the $5-\mathrm{HT}_{2 \mathrm{~A}} / 5-\mathrm{HT}_{2 \mathrm{C}}$ receptors alone (Meert et al. 1989). The role of fluoxetine in regard to the influence of noradrenergic systems on the effects of LSD is not well established, however, because chronic fluoxetine administration leads to modest and equivocal reductions in beta-adrenergic receptor numbers and catecholamine metabolites (Beasley et al. 1992; Hyttel 1994). Further experimentation in these areas would help to evaluate the contribution of catecholamine systems to LSD-SRI interactions.

\section{CONCLUSIONS}

In summary, chronic administration of medically prescribed serotonergic antidepressants to humans substantially attenuated the subjective effects of self-administered LSD, as evaluated using a standardized questionnaire. 
This decrease in hallucinatory and other responses to LSD may occur because of adaptations in serotonergic systems, including alterations in $5-\mathrm{HT}_{1 \mathrm{~A}}$ and $5-\mathrm{HT}_{2 \mathrm{~A}} /$ $5-\mathrm{HT}_{2} \mathrm{C}$ receptors, changes in brain extracellular 5-HT concentrations, or in catecholamine systems. These results are in sharp contrast to the generally enhanced responses to LSD reported using the same questionnaire in individuals receiving tricyclic antidepressants (imipramine, desipramine, clomipramine), lithium, or tricyclic antidepressants plus lithium (Bonson and Murphy in press). Additional investigations of the possible mechanisms underlying alterations in LSD response during antidepressant administration are currently being pursued in our laboratory using behavioral and biochemical experiments in animal models.

\section{ACKNOWLEDGMENTS}

The authors thank the Multidisciplinary Association for Psychedelic Studies (MAPS), as well as all of the scientists and clinicians who became familiar with this study, for their contributions to this study. We also thank the participants of the 1995 Pacific Symposium on Psychedelic Drugs for their useful comments on the interpretation of our data. Finally, we thank Mrs. Wilma Davis for her excellent work in preparing the manuscript.

\section{REFERENCES}

Aghajanian GK, Haigler HJ (1975): Hallucinogenic indoleamines: Preferential action upon presynaptic serotonin receptors. Psychopharmacol Commun 1:619-629

Arnt J (1989): Characterization of the discriminative stimulus properties induced by $5-\mathrm{HT}_{1}$ and $5-\mathrm{HT}_{2}$ agonists in rats. Pharmacol Toxicol 64:165-172

Baron BM, Ogden AM, Siegel BW, Stegeman J, Ursillo RC, Dudley MW (1988): Rapid downregulation of betaadrenoceptors by coadministration of desipramine and fluoxetine. Eur J Pharmacol 154:125-134

Battaglia G, Shannon M, Borgundvaag B, Titeler M (1983): $\mathrm{pH}$-dependent modulation of agonist interactions with $\left[{ }^{3} \mathrm{H}\right]$-ketanserin-labelled $\mathrm{S}_{2}$ serotonin receptors. Life Sci 33:2011-2016

Beasley CM, Masica DN, Potvin JH (1992): Fluoxetine: A review of receptor and functional effects and their clinical implications. Psychopharmacology (Berl) 107:1-10

Bel N, Artigas F (1993): Chronic treatment with fluvoxamine increases extracellular serotonin in frontal cortex but not in raphe nuclei. Synapse 15:243-245

Birkhimer LJ, DeVane CL, Muniz CE (1984): Mechanism and management of important psychotherapeutic drug interactions. South Med J 77:465-469

Blier P, de Montigny C (1983): Electrophysiological investigations on the effect of repeated zimelidine administration on serotonergic neurotransmission in the rat. J Neurosci 3:1270-1278

Bonson KR, Murphy DL (1996): Alterations in responses to
LSD in humans associated with chronic administration of tricyclic antidepressants, monoamine oxidase inhibitors or lithium. Behav Brain Res 73:229-233

Buckholtz NS, Freedman DX, Middaugh LD (1985): Daily LSD administration selectively decreases serotonin 2 receptor binding in rat brain. Eur J Pharmacol 109:421-425

Buckholtz NS, Zhou D, Freedman DX (1988): Serotonin 2 agonist administration downregulates rat brain serotonin 2 receptors. Life Sci 42:2439-2445

Buckholtz NS, Zhou DF, Freedman DX, Potter WZ (1990): Lysergic acid diethylamide (LSD) administration selectively downregulates serotonin 2 receptors in rat brain. Neuropsychopharmacology 3:137-148

Burris KD, Sanders-Bush E (1992): Unsurmountable antagonism of brain 5-hydroxytryptamine 2 receptors by $(+)$-lysergic acid diethylamide and bromo-lysergic acid diethylamide. Mol Pharmacol 42:826-830

Burris KD, Breeding M, Sanders-Bush E (1991): (+)Lysergic acid diethylamide, but not its nonhallucinogenic congeners, is a potent serotonin $5-\mathrm{HT}_{1 \mathrm{C}}$ receptor agonist. J Pharmacol Exp Ther 258:891-896

Burt DR, Creese I, Snyder SH (1976): Binding interactions of lysergic acid diethylamide and related agents with dopamine receptors in the brain. Mol Pharmacol 12:631-638

Caccia S, Fracasso C, Garattini S, Guiso G, Sarati S (1992): Effects of short- and long-term administration of fluoxetine on the monoamine content of rat brain. Neuropharmacology 31:343-347

Callahan PM, Appel JB (1990): Differentiation between the stimulus effects of (+)-lysergic acid diethylamide and lisuride using a three-choice, drug discrimination procedure. Psychopharmacology (Berl) 100:13-18

Closse A, Frick W, Dravid A, Bolliger G, Hauser D, Sauter A, Tobler HJ (1984): Classification of drugs according to receptor binding profiles. Naunyn Schmiedebergs Arch Pharmacol 327:95-101

Colpaert FC, Meert TF, Niemegeers CJ, Janssen PA (1985): Behavioral and 5-HT antagonist effects of ritanserin: A pure and selective antagonist of LSD discrimination in rat. Psychopharmacology 86:45-54

Creese I, Burt DR, Snyder SH (1975): The dopamine receptor: Differential binding of d-LSD and related agents to agonist and antagonist states. Life Sci 17:1715-1719

Cunningham KA, Appel JB (1987): Neuropharmacological reassessment of the discriminative stimulus properties of d-lysergic acid diethylamide (LSD). Psychopharmacology (Berl) 91:67-73

de Montigny C, Aghajanian GK (1978): Tricyclic antidepressants: Long-term treatment increases responsivity of rat forebrain neurons to serotonin. Science 202:1303-1306

de Montigny C, Chaput Y, Blier P (1990): Modification of serotonergic neuron properties by long-term treatment with serotonin reuptake blockers. J Clin Psychiatr 51:4-8

Dumbrille-Ross A, Tang SW (1983): Manipulations of synaptic serotonin: Discrepancy of effects on serotonin $S_{1}$ and $\mathrm{S}_{2}$ sites. Life Sci 32:2677-2684

Dytrych SGZ (1965): Blocking of LSD reaction by premedication with Niamid. Activ Nerv Super (Praha) 7:306

Erlander MG, Lovenberg TW, Baron BM, deLecea L, Daniel- 
son PE, Racke M, Slone AL, Siegel BW, Foye PE, Cannon K, et al (1993): Two members of a distinct subfamily of 5-hydroxytryptamine receptors differentially expressed in rat brain. Proc Natl Acad Sci USA 90:3452-3456

Freedman DX (1969): The psychopharmacology of hallucinogenic agents. Annu Rev Med 20:409-418

Fuller RW (1994): Uptake inhibitors increase extracellular serotonin concentration measured by brain microdialysis. Life Sci 55:163-167

Fuxe K, Ogren S-O, Agnati LF, Benfenati F, Fredholm B, Anderson K, Zini I, Eneroth P (1983): Chronic antidepressant treatment and central 5-HT synapses. Neuropharmacology 22:389-399

Fuxe K, Ogren SO, Agnati LF, Eneroth P, Holm AC, Andersson $K$ (1981): Long-term treatment with zimelidine leads to a reduction in 5-hydroxytryptamine neurotransmission within the central nervous system of the mouse and rat. Neurosci Lett 21:57-62

Gallagher DW, Aghajanian GK (1975): Effects of chlorimipramine and lysergic acid diethylamide on efflux of precursor-formed 3-H-serotonin: Correlations with serotonergic impulse flow. J Pharmacol Exp Ther 193:785-795

Gardier AM, Lepoul E, Trouvin JH, Chanut E, Dessalles MC, Jacquot C (1994): Changes in dopamine metabolism in rat forebrain regions after cessation of long-term fluoxetine treatment: Relationship with brain concentrations of fluoxetine and norfluoxetine. Life Sci 54:PL51-56

Glennon RA (1990): Do classical hallucinogens act as 5- $\mathrm{HT}_{2}$ agonists or antagonists? Neuropsychopharmacology 3 : 509-517

Glennon RA, Titeler M, McKenney JD (1984): Evidence for $5-\mathrm{HT}_{2}$ involvement in the mechanism of action of hallucinogenic agents. Life Sci 35:2505-2511

Glennon RA, Raghupathi R, Bartyzel P, Teitler M, Leonhardt $S$ (1992): Binding of phenylalkylamine derivatives at 5- $\mathrm{HT}_{1 \mathrm{C}}$ and 5- $\mathrm{HT}_{2}$ serotonin receptors: Evidence for a lack of selectivity. J Med Chem 35:734-740

Goff DC, Brotman AW, Waites M, McCormick S (1990): Trial of fluoxetine added to neuroleptics for treatment-resistant schizophrenic patients. Am J Psychiatr 147:492-494

Goldman MJ, Grinspoon L, Hunter-Jones S (1990): Ritualistic use of fluoxetine by a former substance abuser [letter]. Am J Psychiatr 147:1377

Goodnough DB, Baker GB (1994): 5-Hydroxytryptamine 2 and beta-adrenergic receptor regulation in rat brain following chronic treatment with desipramine and fluoxetine alone and in combination. J Neurochem 62:2262-2268

Goodwin GM, Green AR, Johnson P (1984): 5- $\mathrm{HT}_{2}$ receptor characteristics in frontal cortex and $5-\mathrm{HT}_{2}$ receptor-mediated head-twitch behaviour following antidepressant treatment to mice. Br J Pharmacol 83:235-242

Grof S, Dytrych Z (1965): Blocking of LSD reaction by premedication with Niamid. Act Nerv Super (Praha) 7:306

Gross R (1994): Abuse of fluoxetine [letter; comment]. Mayo Clin Proc 69:914

Heninger GR, Charney DS (1987): Mechanism of action of antidepressant treatments: Implications for the etiology and treatment of depressive disorders. In Meltzer HY (ed), Psychopharmacology: The Third Generation of Progress, New York, Raven, pp 535-545
Hensler JG, Ordway GA, Gambarana C, Areso P, Frazer A (1991): Serotonergic neurons do not influence the regulation of beta adrenoceptors induced by either desipramine or isoproterenol. J Pharmacol Exp Ther 256: 656-664

Hoyer D (1989): 5-Hydroxytryptamine receptors and effector coupling mechanisms in peripheral tissues. In Fozard JR (ed), The Peripheral Actions of 5-Hydroxytryptamine, Oxford, Oxford University Press, pp 72-99

Hyttel J (1994): Pharmacological characterization of selective serotonin reuptake inhibitors (SSRIs). Int Clin Psychopharmacol 9:19-26

Kennett GA, Lightowler S, Murphy O, DeBiasi V, Stevens N, Tulloch IF, Blackburn TP (1994): Chronic treatment with paroxetine and fluoxetine, but not desipramine, desensitises $5-\mathrm{HT}_{2 \mathrm{C}}$ receptor function. IUPHAR Satellite Meeting on Serotonin, Chicago, SmithKline Beecham Pharmaceuticals

Klimek V, Zak-Knapik J, MacKowiak M (1994): Effects of repeated treatment with fluoxetine and citalopram, 5-HT uptake inhibitors, on $5-\mathrm{HT}_{1} \mathrm{~A}$ and $5-\mathrm{HT}_{2}$ receptors in the rat brain. J Psychiatry Neurosci 19:63-67

Li Q, Brownfield MS, Battaglia G, Cabrera TM, Levy AD, Rittenhouse PA, van de Kar LD (1993a): Long-term treatment with the antidepressants fluoxetine and desipramine potentiates endocrine responses to the serotonin agonists 6-chloro-2-[1-piperazinyl]-pyrazine (MK212) and (+)-1-(2,5-dimethoxy-4-iodophenyl)-2-aminopropane $\mathrm{HCl}$ (DOI). J Pharmacol Exp Ther 266:836-844

Li Q, Levy AD, Cabrera TM, Brownfield MS, Battaglia G, Van de Kar LD (1993b): Long-term fluoxetine, but not desipramine, inhibits the ACTH and oxytocin responses to the $5-\mathrm{HT}_{1 \mathrm{~A}}$ agonist, $8-\mathrm{OH}-\mathrm{DPAT}$, in male rats. Brain Res 630:148-156

Lovenberg TW, Baron BM, de Lecea L, Miller JD, Prosser RA, Rea MA, Foye PE, Racke M, Slone AL, Siegel BW, Danielson PE, Sutcliffe JG, Erlander MG (1993a): A novel adenylyl cyclase-activating serotonin receptor $\left(5-\mathrm{HT}_{7}\right)$ implicated in the regulation of mammalian circadian rhythms. Neuron 11:449-458

Lovenberg TW, Erlander MG, Baron BM, Racke M, Slone AL, Siegel BW, Craft CM, Burns JE, Danielson PE, Sutcliffe JG (1993b): Molecular cloning and functional expression of $5-\mathrm{HT}_{1 \mathrm{E}}$-like rat and human 5-hydroxytryptamine receptor genes. Proc Natl Acad Sci USA 90:2184-2188

Lucas RA (1992): The human pharmacology of fluoxetine. Int J Obes Relat Metab Disord 16:S49-S54

Maj J, Moryl E (1992): Effects of sertraline and citalopram given repeatedly on the responsiveness of 5-HT receptor subpopulations. J Neural Trans 88:143-156

Maj J, Moryl E (1993): Effects of fluoxetine given chronically on the responsiveness of 5-HT receptor subpopulations to their agonists. Eur Neuropsychopharmacol 3:85-94

Markel H, Lee A, Holmes RD, Domino EF (1994): LSD flashback syndrome exacerbated by selective serotonin reuptake inhibitor antidepressants in adolescents. J Pediatr 125:817-819

Martin-Iverson MT, Leclere JF, Fibiger HC (1983): Cholinergic-dopaminergic interactions and the mechanisms of action of antidepressants. Eur J Pharmacol 94:193-201 
Meert TF, de Haes P, Janssen PA (1989): Risperidone (R64 766), a potent and complete LSD antagonist in drug discrimination by rats. Psychopharmacology 97:206-212

Mittman SM, Geyer MA (1989): Effects of 5HT-1A agonists on locomotor and investigatory behaviors in rats differ from those of hallucinogens. Psychopharmacology 98: $321-329$

Mittman SM, Geyer MA (1991): Dissociation of multiple effects of acute LSD on exploratory behavior in rats by ritanserin and propranolol. Psychopharmacology 105: 69-76

Monsma FJ, Shen Y, Ward RR, Hamblin MW, Sibley DR (1993): Cloning and expression of a novel serotonin receptor with high affinity for tricyclic psychotropic drugs. Mol Pharmacol 43:320-327

Moret C, Briley M (1990a): Modulation by drugs of the release of total tritium and ${ }^{3} \mathrm{H}-5$-HT from rat hypothalamic slices. Naunyn Schmiedebergs Arch Pharmacol 341:398-403

Moret C, Briley M (1990b): Serotonin autoreceptor subsensitivity and antidepressant activity. Eur J Pharmacol 180 351-356

Murphy DL, Aulakh CS, Garrick NA, Sunderland T (1987): Monoamine oxidase inhibitors as antidepressants: Implications for the mechanism of action of antidepressants and the psychobiology of the affective disorders and some related disorders. In Meltzer HY (ed), Psychopharmacology: The Third Generation of Progress, New York, Raven, pp 545-552

Murthy JN, Pranzatelli MR (1992): Brainstem 5-hydroxytrytamine ${ }_{1 \mathrm{~A}}$ binding sites are not downregulated by agonists which induce tolerance in the rat: Myoclonus and other serotonergic behaviors. J Recept Res 12:287-197

Newman ME, Lerer B, Shapira B (1993): 5-HT-1A receptormediated effects of antidepressants. Prog Neuropsychopharmacol Biol Psychiatr 17:1-19

Nielsen EB (1985): Discriminative stimulus properties of lysergic acid diethylamide in the monkey. J Pharmacol Exp Ther 234:244-249

Nielsen EB, Ginn SR, Cunningham KA, Appel JB (1985): Antagonism of the LSD cue by putative serotonin antagonists: Relationship to inhibition of in vivo [ $\left.{ }^{3} \mathrm{H}\right]$ spiroperidol binding. Behav Brain Res 16:171-176

Pagliaro LA, Pagliaro AM (1993): Fluoxetine abuse by an intravenous drug user. Am J Psychiatr 150:1898

Pato MT, Murphy DL, DeVane CL (1991): Sustained plasma concentrations of fluoxetine and/or norfluoxetine four and eight weeks after fluoxetine discontinuation. J Clin Psychopharmacol 11:224-225

Penington NJ, Fox AP (1994): Effects of LSD on $\mathrm{Ca}^{-+}$currents in central 5-HT-containing neurons: $5-\mathrm{HT}_{1 \mathrm{~A}}$ receptors may play a role in hallucinogenesis. J Pharmacol Exp Ther 269:1160-1165

Peroutka SJ, Snyder SH (1980): Long term antidepressant treatment decreases spiroperidol-labeled serotonin receptor binding. Science 210:88-90

Pierce PA, Peroutka SJ (1988): Antagonism of 5-hydroxytryptamine $_{2}$ receptor-mediated phosphatidylinositol turnover by d-lysergic acid diethylamide. J Pharmacol Exp Ther 247:918-925

Pierce PA, Peroutka SJ (1989): Hallucinogenic drug interac- tions with neurotransmitter receptor binding sites in human cortex. Psychopharmacology 97:118-122

Pierce PA, Kim JY, Peroutka SJ (1992): Molecular structural basis of ligand selectivity for $5-\mathrm{HT}_{2}$ versus $5-\mathrm{HT}_{1 \mathrm{C}}$ cortical receptors. Naunyn Schmiedebergs Arch Pharmacol 346:4-11

Pieri L, Pieri M, Haefely W (1974): LSD as an agonist of dopamine receptors in the striatum. Nature 252:586-588

Resnick O, Krus DM, Raskin M (1964): LSD-25 Action in normal subjects treated with a monoamine oxidase inhibitor. Life Sci 3:1207-1214

Sadzot B, Baraban JM, Glennon RA, Lyon RA, Leonhardt S, Jan C-R, Titeler M (1989): Hallucinogenic drug interactions at human brain 5- $\mathrm{HT}_{2}$ receptors: Implications for treating LSD-induced hallucinogenesis. Psychopharmacology 98:495-499

Sanders-Bush E, Breeding M (1988): Putative selective 5- $\mathrm{HT}_{2}$ antagonists block serotonin $5-\mathrm{HT}_{1 \mathrm{C}}$ receptors in the choroid plexus. J Pharmacol Exp Ther 247:169-173

Sanders-Bush E, Burris KD, Knoth K (1988): Lysergic acid diethylamide and 2,5-dimethoxy-4-methylamphetamine are partial agonists at serotonin receptors linked to phosphoinositide hydrolysis. J Pharmacol Exp Ther 246:924-928

Schechter LE, Bolanos FJ, Gozlan H, Lanfumey L, Haj DS, Laporte AM, Fattaccini CM, Hamon M (1990): Alterations of central serotoninergic and dopaminergic neurotransmission in rats chronically treated with ipsapirone: Biochemical and electrophysiological studies. J Pharmacol Exp Ther 255:1335-1347

Sleight AJ, Carolo C, Petit N, Zwingelstein C, Bourson A (1995): Identification of 5-hydroxy tryptamine, receptor binding sites in rat hypothalamus: Sensitivity to chronic antidepressant treatment. Mol Pharmacol 47:99-103

Snyder SH, Peroutka SJ (1982): A possible role of serotonin receptors in antidepressant drug action. Pharmacopsychiatria 15:131-134

Spina E, Perucca E (1994): Newer and older antidepressants: A comparative review of drug interactions. CNS Drugs $2: 479-497$

Spyraki C, Fibiger HC (1981): Behavioural evidence for supersensitivity of postsynaptic dopamine receptors in the mesolimbic system after chronic administration of desipramine. Eur J Pharmacol 74:195-206

Stolz JJ, Marsden CA, Middlemiss DN (1983): Effect of chronic antidepressant treatment and subsequent withdrawal on $\left[{ }^{3} \mathrm{H}\right]-5$-hydroxytryptamine and $\left[{ }^{3} \mathrm{H}\right]$-siperone binding in rat frontal cortex and serotonin receptor mediated behaviour. Psychopharmacology 80:150-155

Strassman RJ (1984): Adverse reactions to psychedelic drugs. A review of the literature. J Nerv Ment Dis 172:577-595

Strassman RJ (1992): Human hallucinogen interactions with drugs affecting serotonergic neurotransmission. Neuropsychopharmacology 7:241-243

Tinsley JA, Olsen MW, Laroche RR, Palmen MA (1994): Fluoxetine abuse. Mayo Clin Proc 69:166-168

Titeler M, Lyon RA, Glennon RA (1988): Radioligand binding evidence implicates the brain $5-\mathrm{HT}_{2}$ receptor as a site of action for LSD and phenylisopropylamine hallucinogens. Psychopharmacology (Berl) 94:213-216

Trulson ME, Crisp T (1986): Do) serotonin-containing dorsal 
raphe neurons possess autoreceptors? Exp Brain Res 62: 579-586

Trulson ME, Heym J, Jacobs BL (1981): Dissociations between the effects of hallucinogenic drugs on behavior and raphe unit activity in freely moving cats. Brain Res 215:275-293

U.S. DHHS (1993): National Household Survey on Drug Abuse-Population Estimates of 1993, Substance Abuse and Mental Health Services Administration, US Department of Health and Human Services, DHHS Publication \# (SMA)-94-3017, Washington, DC, U.S. Government Printing Office

Wamsley JK, Byerley WF, McCabe RT, McConnell EJ, Dawson TM, Grosser BI (1987): Receptor alterations associated with serotonergic agents: An autoradiographic analysis. J Clin Psychiatr 48:19-25

Westphal RS, Sanders-Bush E (1994): Reciprocal binding properties of 5-hydroxytryptamine type $2 \mathrm{C}$ receptor agonists and inverse agonists. Mol Pharmacol 46:937-942

White FJ, Holohean AM, Appel JB (1983): Antagonism of a behavioral effect of LSD and lisuride in the cat. Psychopharmacology (Berl) 80:83-84

Wilcox JA (1987): Abuse of fluoxetine by a patient with anorexia nervosa [letter]. Am J Psychiatr 144:1100

Willner P (1989): Sensitization to the actions of antidepressant drugs. In Goudie AJ, Emmett-Oglesby MW (eds), Psychoactive Drugs: Tolerance and Sensitization, Clifton, NJ, Humana Press, pp 407-459

Winter JC, Rabin RA (1988): Interactions between serotonergic agonists and antagonists in rats trained with LSD as a discriminative stimulus. Pharmacol Biochem Behav $30: 617-624$ 